\title{
Volunteering and Income - The Fallacy of the Good Samaritan?
}

\author{
Franz Hackl ${ }^{1}$, Martin Halla ${ }^{2}$ \& Gerald J. Pruckner ${ }^{3}$
}

forthcoming in Kyklos, Vol. 60(1), 2007.

\footnotetext{
${ }^{1}$ Department of Economics, Johannes Kepler University of Linz, Altenbergerstr. 69, A-4040 Linz, Austria, email: franz.hackl@jku.at

${ }^{2}$ Department of Economics, Johannes Kepler University of Linz, Altenbergerstr. 69, A-4040 Linz, Austria, email: martin.halla@jku.at

${ }^{3}$ Department of Economics, Johannes Kepler University of Linz, Altenbergerstr. 69, A-4040 Linz, Austria, email: gerald.pruckner@jku.at
} 


\begin{abstract}
This paper explores individual motives for volunteering. The analysis is based on the interpretation of volunteering as a consumption good (consumption model) or as a mean to increase individual's own human capital (investment model). We present an econometric framework taking into account self selection into volunteering and simultaneity between the volunteering decision and the determination of income in order to test these two models and to identify the underlying motives.

We find strong statistical evidence for the investment model with a highly robust and significant impact of volunteering on the wage rate. Within the framework of the investment model it turns out that the number of volunteering hours plays a major role in explaining this wage premium. This supports the significance of skill acquisition to accumulate human capital, the importance of deepening of social contacts and signalling willingness to perform. As far as the consumption model is concerned we find no clear statistical evidence for its validity.
\end{abstract}

Keywords: volunteering, voluntary labour supply, human capital accumulation, wage premium, altruism.

JEL classification: J22, J24, J31, D64. 


\section{Introduction}

Economists usually assume positively sloped labour supply curves with reservation wages different from zero. In contrast to this view a considerable amount of labour is offered without monetary compensation in return throughout the economy. Neighbourly help or other unpaid help for friends are good examples for the social phenomenon that people donate time and effort in the absence of monetary rewards. Moreover, there is a significant percentage of people who offer voluntary work in numerous organisations worldwide. Important fields of volunteering comprise social and health services, education and youth work, culture and recreation, rescue organisations, politics, environmental and religious services. Undoubtedly, volunteering contributes significantly to the economy's welfare that would otherwise require paid resources.

The share of the population offering formal voluntary labour varies strongly across countries (Table1). Sweden exhibits the highest participation rate in Europe with a share of 59 percent of all employed people who supply voluntary labour. It is followed by Slovakia (55 percent) with a participation rate above 0.50. Denmark, Greece, Great Britain and The Netherlands show participation rates between 0.41 and 0.49. Italy, Luxembourg, Iceland, Malta, Slovenia, Austria, Czech Republic, Ireland, Belgium and Finland have values between 0.31 and 0.39. In Germany, Estonia, Spain, Belarus, Northern Ireland, Bulgaria, Croatia, Romania, Latvia and France at least 21 percent of all employed people participate in voluntary labour. The group of countries with the lowest participation rates with values between 0.10 and 0.19 are Turkey, Russia, Ukraine, Hungary, Poland and Lithuania. In the United States participation rates are stable around 0.30 in recent years (Bureau of Labor Statistics, 2002, 2003, 2004, 2005). The important role of voluntary activities for the social and economic life and the high participation rates necessitate a thorough economic analysis of motives for voluntary labour supplied.

Since volunteering cannot be explained by traditional labour market theory we build on a different approach introduced by Menchik and Weisbrod (1987). According to this approach volunteering can be conceived either as a consumption or as an investment good. In the consumption model volunteering reflects a utility-bearing activity. Hence, a utility maximising consumer will choose voluntary activities according to her preference structure under a given income constraint. As will be argued later we comprehend intrinsic motives in this consumption motive. Within the investment hypothesis voluntary activities cause opportunity cost as time and effort is devoted in order to increase someone's income in the paid labour market. Therefore, the level of income is determined by the amount of voluntary labour supply. 
An empirical investigation of these models ${ }^{1}$ is confronted at least with the following problems: First, the empirical analysis has to control for potential simultaneity between income and the volunteering decision. Second, self selection of volunteers must be expected in the sense that volunteers differ systematically to non-volunteers in (un)observed characteristics. Third, it is difficult to test comprehensively the underlying motives behind the consumption and investment model.

In this paper we tackle these issues by use of advanced regression and propensity score matching methods and thereby controlling for potential endogeneity caused by simultaneity and self selection. Based on Austrian Census data on volunteers in organisations we try to identify evidence in support of the investment and/or the consumption model. Moreover, we test different motives of volunteers in either approach. The proposal is innovative as existing contributions limit their analysis on either the consumption or the investment model and do not account for potential simultaneity. Furthermore, in contrast to existing literature we measure volunteering in three dimensions: as a dichotomous variable, as the number of hours individuals volunteer, and as the number of organisations they are engaged with.

\section{The Rationale of Volunteering}

In this section the motives for volunteering are formally specified. Based on the consumption model voluntary activities may appear as an argument in the following maximisation problem of a utility function $U_{i}$ for an individual $i$ subject to an income and time constraint

$$
\max U_{i}\left(t_{L}, t_{V}, C\right) \quad \text { s.t. } \quad C=w\left(T-t_{L}-t_{V}\right)
$$

The fact that voluntary work is time consuming implies that for each offered hour opportunity cost have to be accepted: The variables $t_{L}$ and $t_{V}$ represent the hours of leisure activities and the hours spent for voluntary work. The variable $C$ denotes conventional consumption expenditures (numeraire). The income constraint is defined by the product of the wage rate $w$ and the working hours $T-t_{L}-t_{V} \geq 0$. The variable $T$ stands for the endowment of available time. Hence, by providing an additional hour of volunteering individual income is affected. If the wage rate changes the allocation of time and, therefore, income will change as well. An increasing (decreasing) wage rate will be associated with a decline (increase) of voluntary work due to the substitutional relationship between paid work and volunteering. If the wage rate has no influence on the amount of volunteering this may either indicate a certain type of preference structure or invalidate the consump-

\footnotetext{
${ }^{1}$ The following analysis of volunteering concentrates on the supply side. On the demand side we assume a perfectly elastic relationship for volunteers at zero wages.
} 
tion model. Therefore, the conclusion that a missing empirical correlation between wage and volunteering undoubtedly indicates the irrelevance of the consumption model seems premature since substitution and income effects of a change in the wage rate may cancel out. Based on the consumption model the following suppositions can be derived:

- Supposition 1: A significant influence of income on volunteering supports the validity of the consumption model.

- Supposition 2: Controlling for income the number of working hours is expected to have a negative effect on volunteering.

In contrast to the consumption model the main purpose of volunteering in the investment model is accumulation of human capital. Hence, volunteering will increase future income as voluntary workers acquire certain types of skills and create and develop networks which are useful for their paid job. Whereas the consumption model can be formulated within a static framework, the investment approach necessitates a dynamic structure. Therefore, volunteering within the simplest form of an investment model is expressed as the outcome of the following individual dynamic maximisation problem:

$$
\begin{gathered}
\max \underset{v(t)}{\mathrm{NPY}}=\int_{0}^{T} f(v(t), h(t)) e^{-r t} d t \quad \text { s.t. } \dot{h}(t)=g(v(t))-\delta h(t) \\
\text { with } \frac{\partial f(v(t), h(t))}{\partial v(t)}<0, \frac{\partial f(v(t), h(t))}{\partial h(t)}>0 \text { and } \frac{\partial g(v(t))}{\partial v(t)}>0 .
\end{gathered}
$$

In this intertemporal optimisation problem an individual maximises her net present income which is the integral of a production function $f(\bullet)$ over the time span $[0, T]$. The variable $T$ can be associated with the age of retirement. In the production function $v(t)$ represents the amount of volunteering activities, and $h(t)$ denotes accumulated human capital. Whereas an increase in volunteering will decrease the current income level, an increase in human capital will raise future individual income. As indicated by $g(v(t))$ in the equation of motion volunteering pays off in the sense that investment in volunteering today - although reducing current income - will increase future human capital and, therefore, future income levels. The depreciation of the human capital stock over time is denoted by $\delta h(t)$. The solution to this standard dynamic optimisation problem ${ }^{2}$ is the optimal time path of volunteering which is characterised by high volunteering at the beginning of the time span. Thereafter, voluntary labour supply decreases steadily over time. The optimal volunteering time path follows a typical inverse U-shaped human capital curve. However, the model does not necessarily predict that every individual would have an incentive to offer voluntary labour. If the loss in current income through volunteering is expected to

\footnotetext{
${ }^{2}$ This model is based on education decisions in the theory of human capital. For a good introduction, see Cahuc and Zylberberg (2004).
} 
be higher than future returns from volunteering the amount of voluntary labour comes down to zero.

The function $g(\bullet)$ in (2) allows the discussion of different investment-based motives how volunteering may augment the stock of human capital. (i) One explanation for $g(\bullet)$ is on-the-job training and the acquisition of useful skills resulting from volunteering in organisations (Mueller, 1975). Volunteering may be used to learn job-specific requirements and acquire insider know-how to be utilised as a comparative advantage in future recruitment. (ii) Volunteering enables the access to networks (Saloner, 1985) through which people obtain better job opportunities, support through lobbying, or access to important information. (iii) The function $g(\bullet)$ can also be motivated by signalling motives: Potential employees use their volunteering activities in order to demonstrate their ability and willingness to perform, which means volunteering is used to 'boost' curricula vitae. Katz and Rosenberg (2005) provide a theoretical model of volunteering associated with signalling: volunteering individuals emit a signal of high productivity and cooperation and are, therefore, more likely to be hired and to command a higher wage. (iv) Moreover, volunteering may be interpreted as a temporary commitment combined with the idea that monetary compensation will be obtained in the future when unpaid voluntary activities reach a profitable level (e. g. volunteering activities which are commercially sourced out to the volunteer if a certain level of temporal burden is exceeded). Volunteering can then be seen as a vehicle for the preparation of lucrative markets (see Cugno and Ferrero (2004)). Obviously, the potential for this volunteering motive is substantially limited to certain types of volunteering activities. (v) Given the fact that the stock of human capital will depreciate faster for those who are (temporarily) not on the job, volunteering may be used to compensate this decline of human capital (Mueller, 1975). In the dynamic setting above the optimal response would, therefore, lead to higher amounts of voluntary activities over time for those temporarily not on the job. Based on the investment model the following empirically testable suppositions can be extracted:

- Supposition 3: A positive impact of volunteering on the level of income is expected. This causal effect allows the estimation of a wage premium the size of which is of primary interest.

- Supposition 4: Based on the expectation that investment in human capital decreases over time older people are expected to volunteer less then younger ones. A direct effect that older people profit less from long-term benefits derived from voluntary work (e. g. benefits of preserving resources in environmental organisations) may also exist.

- Supposition 5: Since the acquisition of useful skills requires exercise the wage premium is expected to increase with the number of voluntary hours supplied. This 
positive influence is supported by further arguments. On the one hand the number of voluntary hours may express an individual's willingness to perform. On the other hand additional voluntary hours might intensify the social contacts within the network through which higher monetary payoffs can be expected (e.g. to get hold of important information). However, an optimal number of volunteering hours can be supposed beyond which the engagement in volunteering might appear counterproductive. Extensive volunteering might signal too little time for the paid job.

- Supposition 6: As far as other network arguments are concerned the wage premium depends on the number of social contacts and, hence, the number of organisations for which people volunteer.

- Supposition 7: The more influential and the broader the potential network of a volunteering organisation the higher is the supposed wage premium.

- Supposition 8: In order to compensate for the loss of human capital unemployed people and people willing to enter the labour force (again) will volunteer with a higher probability and with a higher intensity than others.

\section{$3 \quad$ Volunteering in the Literature}

Obviously, volunteering is a complex phenomenon the explanation of which transcends the limits of one single approach as different disciplines such as psychology, sociology, economics, anthropology and others offer different and sometimes contradictory insights into the motives for volunteering (Ziemek, 2003; Katz and Rosenberg, 2005). The aim of this paper is neither to provide a comprehensive theory of volunteering nor to invalidate other disciplines. We rather try to identify economic explanations for voluntary labor supply in organisations within the framework of the consumption and the investment model and test those empirically.

The motivational reasons to explain volunteering behaviour can also be classified into the following two groups: One group focuses on internal rewards due to intrinsic motivation originating from helping others. Meier (2006) distinguishes three subcomponents of intrinsic motivators: (i) People care about the recipients' utility and benefit from the result of their effort (Argyle, 1999); (ii) Volunteers enjoy their work per se and intrinsically benefit from the act of volunteering (Deci, 1975; Frey, 1997; Deci and Ryan, 2000). According to this voluntary activity may increase individual self-determination and contribute to feelings of competence. (iii) Helping others triggers warm-glow benefits as the knowledge of conducing to a good cause is utility increasing (Andreoni, 1990). From an economic point of view this intrinsic motives is covered by the consumption motive. The 
other group of motives does not refer to the enjoyment of volunteer behavior per se but to the increase in utility due to extrinsic reward from volunteering. The act of volunteering per se is of secondary interest in this case, and the volunteers rather expect external benefits or payoffs. This group of motives can be subsumed under the investment model.

A comprehensive body of literature stresses altruistic motives for voluntary activities. Even though different concepts and explanations for altruism are provided in the literature, and an unambiguous classification of altruistic motives does not exist, we argue that the consumption model comprehends components of altruistic preferences. In their criticism of a narrow self-interest assumption of traditional economic thought Frey (1997), Frey and Goette (1999), Meier and Stutzer (2004), Govekar and Govekar (2002), and Stark (1995) stress the importance of cooperation, caring for others and philanthropic attitudes to explain individual behaviour (Stark, 1995). Two recent empirical papers confirm the importance of altruism in explaining volunteering: Hwang, Grabb and Curtis (2005) find that Americans are more likely than Canadians to mention altruistic rather than personal reasons for joining voluntary organisations. Results by Cappellari and Turati (2004) support their theoretical predictions indicating that intrinsically motivated individuals are more likely to volunteer than extrinsically motivated ones.

\subsection{Volunteering as Consumption}

Mueller (1975) analyses voluntary hours of women with special attention on altruistic motives using OLS estimations. Another OLS estimation of voluntary hours is supplied by Dye (1980). Whereas income remains insignificant in both analyses, empirical results show a significant positive influence of private wealth on the provision of voluntary labour in the latter one. Empirical evidence on volunteering based on the estimation of a single equation is also presented by Schram and Dunsig (1981). This paper is restricted to married women, uses an OLS estimation to explain the volunteering decision and finds a negative influence of age on the probability to volunteer. Unger (1991) interprets volunteering as a self sacrifice with no apparent reward and finds empirical support for altruism with volunteering to be motivated by a person's perception of the needs of others in the community.

Andreoni, Gale and Scholz (1996) apply a bivariate Probit model for the simultaneous estimation of spending time and money and find a net wage elasticity of voluntary labour of -0.8. They show that changes in the opportunity cost of time have substantial effects on the provision of volunteer hours. The simultaneity between income and volunteering, however, has not been addressed.

Based on a Probit estimation Schady (2001) finds a positive correlation between income 
on volunteering. This confirms the results of Freeman (1997) who argues that volunteering is a so-called 'conscience-good' meaning that people feel morally obligated to volunteer if they are asked to do so. He shows that the rich are addressed to volunteer more frequently since they are expected to be more productive than people with lower income. This might explain the empirically measured positive influence of income on volunteering. However, both studies do neither consider self-selection nor simultaneity problems. Bryant, JeonSlaughter, Kang and Tax (2003) emphasise whether an individual was asked to volunteer or not and control for potential selection bias. Although Carlin (2001) controls for self selection and finds support for the consumption model, the problem of simultaneity is ignored. Segal and Weisbrod (2002) are the the first who stress the heterogeneity of volunteering in empirical work. They use Probit estimations to explain volunteering in health, education and religious services.

\subsection{Volunteering as Investment}

Only a few empirical articles attempt to explore the causal effect of voluntary activities on the wage rate. Using Canadian data Day and Devlin (1997) examine whether volunteering generates a return in the paid labour market and whether this may help to explain part of the male-female earnings gap. Not controlling for potential endogeneity of volunteering they find a significant positive wage premium for male volunteers but not for volunteering women. Using the same data Day and Devlin (1998) find that on average volunteers earn about 7 percent higher incomes than non-volunteers. The econometric specification neglects the possible bias due to endogeneity of volunteering and abstains from separate estimations for men and women. Using improved data and a Heckman self selection procedure Devlin (2000) finds a lower wage premium of about 4 percent. The most recent contribution by Prouteau and Wolff (2005) applies an endogenous switching regression model to French data. Thereby, no statistically significant wage premium for volunteers can be found. The data is, however, restricted to volunteers who perform managerial tasks.

\subsection{A Combination of the Investment and Consumption model}

Several papers try to consider both the consumption and investment model for volunteering. A positive influence of income on egoism motivation representing the consumption model is found in Clary, Snyder and Stukas (1996). Neglecting simultaneity issues the authors also argue that investment considerations play a less important role for volunteers with higher income levels. The empirical analysis in Menchik and Weisbrod (1987) is based on Tobit estimations of voluntary hours supplied. However, the explanation of 
both consumption and investment motives by one single equation must be criticised from an econometric perspective. Vaillancourt (1994) stresses that both consumption and investment play a role for individuals in their decision to volunteer. However, the employed Probit estimation of the volunteering decision including usual socio-economic variables may again be seen as a shortcoming of this empirical analysis. Day and Devlin (1996) investigate whether government spending and voluntary work are substitutes or complements. They suspect the potential endogeneity of income in the volunteering decision, attempt to control for it, but do not estimate a complete structural model. Their empirical results are in line with Menchik and Weisbrod (1987) and Vaillancourt (1994), however, the shortcoming that simultaneity is not adequately addressed still adheres.

Even though single articles do distinguish between consumption and investment motives and also correct for self selection, the potential simultaneity between the decision to volunteer and making income has not been adequately addressed in the literature.

\section{Data}

The following empirical analysis is based on survey data of the Upper Austrian Census conducted in summer 2001. In supplement to the regular Census program with a sample size of about 8000 a sub-sample of 2536 households was confronted with questions about volunteering. ${ }^{3}$ In each household one person was interviewed at her place of residence. In addition data of an accompanying postal survey among 904 Upper Austrian volunteers (mainly volunteering for the Red Cross) have been made available. Income is measured on a monthly base as net household income including all subsidies (e.g. child support) in seven ranges of $€ 727$ length each. The lowest interval indicates income below $€ 727$. We use interval midpoints and $€ 4,724$ for the highest interval as income measures. Since the empirical tests of Suppositions 1-8 necessitate personal income we restrict our analysis to (self-)employed sole wage earners (household income equals personal income) which reduces the sample size to 650 cases.

Standard labour economics uses hourly wage rates. Therefore, in accordance with a traditional wage equation framework we have divided income by the monthly working hours. As a consequence, this wage rate we will be used in the following econometric analysis. Due to missing observations in several variables the sample further diminishes to 421 observations. Out of these 421 observed individuals 162 persons volunteer, they provide on average 29.55 hours per month and work for 1.48 organisations. Concerning the type of the organisations (multiple answers possible) about half of all volunteers

\footnotetext{
${ }^{3}$ For a more detailed description of the survey, see Hackl and Pruckner (2003) or Altenstraßer et al. (2002).
} 
(82 individuals or 50.6\%) are engaged with a relief organization ${ }^{4}$. Political or cultural organisations account for the second-largest group (40 volunteers or 24.7\%). The thirdlargest group consists of social or religious organisations (32 volunteers or 24.7\%). Another 20 volunteers $(12.4 \%)$ perform activities for sports or educational organisations, and 23 volunteers $(14.2 \%)$ volunteer for other organisations. Although most of the voluntary institutions in our data set are organised via a national umbrella organisation most of volunteering is done at the place of residence and, therefore, shows a strong component of local personal involvement. The decision to volunteer is motivated by a variety of factors (multiple answers possible). The majority of volunteers (77.8\%) agrees that 'enjoyment' is an important reason for their volunteering. The other most frequently reported important reasons are 'sensible recreational activity' (52.5\%), 'group/teamwork experience' (48.8\%) and 'social attitude' $(45.7 \%)$. The least frequently reported reasons are to 'make a change from the paid job' (28.4\%), 'gives the feeling of being needed' (27.8\%), 'professional or personal development' (25.3\%), 'personal acknowledgement' (14.8\%) and 'fun with contests' $(13.0 \%)$. With respect to these self-reported motivational factors of volunteers the investment motive seems to be of second order importance.

Our data set on volunteering is cross sectional. The fact that we do not observe individuals over time and have no data on the hitherto duration of volunteering activities complicates the analysis of the investment motive with its inherent time consuming process of human capital accumulation. Nevertheless, the data allow valuable insights into the investment motive since several effects of volunteering on human capital work immediately (e.g. access to the infrastructure of the volunteering organisation, signalling of willingness to perform). Moreover, the typical volunteer has been volunteering for many years and, therefore, the human capital accumulation process is already observable in our data (e.g. the average number of years people volunteer for the Red Cross in Austria is 9 years). Based on these arguments the available data set is appropriate to validate the consumption and investment hypotheses.

\section{$5 \quad$ Estimation Strategy and Empirical Results}

For the empirical test of our suppositions we have both estimated a wage equation using OLS and the probability to volunteer by use of a PROBIT estimation in a first step (see Table 2). ${ }^{5}$ Given that the probability to work for free is positively associated with income we find preliminary evidence for the validity of the consumption motive. Assuming the reversed causal direction the significant volunteer variable in the wage equation indicates the existence of the investment motive with a wage premium of 23.6 percent. Obviously,

\footnotetext{
${ }^{4}$ From these 82 volunteers 68 work for the Red Cross.

${ }^{5}$ For a detailed description and calculation of all variables, see Table 4.
} 
both equations neglect the consequences of presumable endogeneity with the potential to invalidate the conclusions drawn on these two single equation results.

In order to cope with the obvious problem of causal interference and endogeneity we apply an instrumental variable approach in which we first analyse whether the consumption and/or the investment model may explain voluntary labour supply at all. Subsequently, we identify the respective underlying motives and mechanisms. We apply the following system of equations: ${ }^{6}$

$$
\begin{aligned}
& \text { volunteering }=\alpha_{1}+\beta_{1} \text { wage }+\gamma_{\mathbf{1}} \mathbf{X}_{\mathbf{1}}+u_{1} \\
& \text { wage }=\alpha_{2}+\beta_{2} \text { volunteering }+\gamma_{\mathbf{2}} \mathbf{X}_{\mathbf{2}}+u_{2}
\end{aligned}
$$

where wage is the hourly wage rate, $\mathbf{X}_{\mathbf{1}}$ and $\mathbf{X}_{\mathbf{2}}$ represent vectors of individual socioeconomic characteristics, and $\alpha, \beta$ and $\gamma$ symbolise the coefficients to be estimated. The variables $u_{1}$ and $u_{2}$ denote the error terms. The variable volunteering is captured in three different dimensions: (i) a dichotomous variable volunteer is equal to one if the individual volunteers and zero otherwise, (ii) the number of hours individuals volunteer per month volunteer hours, and (iii) the number of organisations they are engaged with \#organisations.

Since tests for endogeneity strongly indicate the prevalence of simultaneity between volunteering and the wage rate and self selection of volunteers we apply appropriate twostep procedures for the estimation of simultaneous equation models. ${ }^{7}$

The distinctive data types of the volunteering variables require different methods of estimation. For the joint estimation of the dichotomous variable volunteer and $\ln$ (wage) we employ a Two-Stage Probit Least Squares Estimation (2SProbitLS) proposed by Maddala (1983, p. 244):

$$
\begin{aligned}
& \text { volunteer }^{*}=\alpha_{11}+\beta_{11} \ln (\text { wage })+\gamma_{\mathbf{1 1}} \mathbf{X}_{\mathbf{1 1}}+u_{11} \\
& \ln (\text { wage })=\alpha_{21}+\beta_{21} \text { volunteer }+\gamma_{\mathbf{2 1}} \mathbf{X}_{\mathbf{2 1}}+u_{21} \\
& \text { volunteer }=1\left[\text { volunteer }^{*}>0\right]
\end{aligned}
$$

The latent variable volunteer hours is censored at zero hours. Therefore, we use a TwoStage Tobit Least Squares Estimation (2STOBITLS) and estimate the volunteering equations by an Amemyia Generalised Least Squares Estimator (AGLS) (Amemiya, 1978;

\footnotetext{
${ }^{6}$ Subscripts denoting individuals are omitted for simplicity.

${ }^{7}$ The empirical results of endogeneity tests will be discussed below.
} 
Newey, 1987) and the wage equation following Maddala (1983, p. 243):

$$
\begin{aligned}
& \text { volunteer hours }{ }^{*}=\alpha_{12}+\beta_{12} \ln (\text { wage })+\gamma_{\mathbf{1 2}} \mathbf{X}_{\mathbf{1 2}}+u_{12} \\
& \ln (\text { wage })=\alpha_{22}+\beta_{22} \text { volunteer hours }+\gamma_{\mathbf{2 2}} \mathbf{X}_{\mathbf{2 2}}+u_{22} \\
& \text { volunteer hours }=\max \left[0, \text { volunteer hours }{ }^{*}\right]
\end{aligned}
$$

The same estimation procedure is applied for the joint estimation of the censored variable \#organisations and $\ln$ (wage):

$$
\begin{aligned}
& \text { \# } \text { organisations }^{*}=\alpha_{13}+\beta_{13} \ln (\text { wage })+\gamma_{\mathbf{1 3}} \mathbf{X}_{\mathbf{1 3}}+u_{13} \\
& \text { ln }(\text { wage })=\alpha_{23}+\beta_{23} \# \text { organisations }+\gamma_{\mathbf{2 3}} \mathbf{X}_{\mathbf{2 3}}+u_{23} \\
& \text { \#organisations }=\max \left[0, \text { \#organisations }{ }^{*}\right]
\end{aligned}
$$

Both the wage and volunteering equations include a set of socio-economic variables such as education, working experience, sex, family status, place of residence, and working hours in the paid job. ${ }^{8}$ Since the number of minors cannot be included in the regressions due to missing data we control for the number of household members. In addition the wage equations contain whether a person works in shifts or not and whether she is a blue or white collar worker. The volunteering equation is identified by the following exclusive restrictions: whether or not an individual has been engaged in a club during childhood and adolescence and whether or not the individual has a volunteering partner. Both variables are highly correlated with the individual's decision to volunteer. Both variables are not correlated with unobserved wage-enhancing characteristics. As far as the variable partner volunteers is concerned joint coordination of (leisure) time and imitation of partner's behaviour represent good reasons for the influence of the partner's volunteering. It is not obvious that the volunteering behaviour of the partner would be correlated with the residual in the wage equation of the individual. For instance, if there is positive assortative mating of unobserved wage enhancing characteristics of cohabiting partners, the application of this instrument would be problematic. However, we do not find literature supporting the existence of assortative mating of unobserved wage enhancing characteristics. In general, there has been little conclusive evidence favouring the assortative mating hypothesis of observable characteristics (Liu and Zhang, 1999). As regards the variable youth club the innate ability of a child does not decide whether she participates in a youth club in general. Given participation in youth clubs, however, the abilities and of course preferences will determine the type of the youth club. The contact with club life and companionship increases the probability to join volunteering organisations years later. Recognising the value of youth clubs for the development of children it is not plausible that children in youth clubs utilise these clubs to accumulate human capital and to build

\footnotetext{
${ }^{8}$ In the following analysis we implicitly assume that individuals choose the working hours in the paid labour market before they decide on the amount of volunteering. For further discussion of the issue, see Carlin (2001).
} 
social networks in order to find better-paying jobs when they are grown up. With the exception of wage instruments in the number of organisations equation, the validity of all our instruments is approved by overidentification tests with high probabilities (see lower panel in Table 3$)$.

Table 3 includes the estimation results for the three different types of estimation models. The lower panel includes the tests for endogeneity and tests for overidentification. The volunteering variables (volunteer, volunteer hours and \#organisations) are correlated with the structural error in the wage equation with a probability of 90.8 percent, 99.6 percent and 99.6 percent. Therefore, we have a strong evidence for the prevalence of the presumed endogeneity of volunteering. Endogeneity of income in the volunteering equation occurs with lower probabilities: 0.6 percent, 54.0 percent and 5.2 percent. Nevertheless, we apply the instrument variable estimation strategy as well.

Estimation results show that volunteers receive a wage premium in the paid labour market. Irrespective of the volunteering variable to be used and the applied estimation technique volunteers earn a significantly higher wage as compared to non-volunteers (Supposition 3). Whereas the wage premium for participating in voluntary work is on average 18.5 percent based on the 2SPRoBITLS model, the 2STOBITLS regression estimates a wage premium of 0.60 percent for one additional hour of voluntary labour per month, and 17.0 percent higher wages if an individual volunteers for an additional organisation. The robust and highly significant impact of volunteering on wages supports the importance of the investment model to explain voluntary work. All other coefficients in the wage equations are of reasonable order of magnitude and show theoretically expected signs. Uncommonly we do not observe a significant wage differential between men and women, which might result from observing single earners only.

In contrast to the investment motive we do not find clear evidence for the validity of the consumption model. The coefficient of $\ln$ (wage) in the volunteering equation remains insignificant in all three variants (Supposition 1). The same is true for the variable workhours in two of the three volunteering equations (Supposition 2). In the volunteer hours equation the number of working hours in the paid job enter statistically significant with a positive sign. Moreover, one should also bear in mind that endogeneity tests of income in the volunteering equations suggest exogeneity of income in two out of three cases. Given these results we get ambiguous evidence concerning the consumption model. A series of papers based on single equation models of volunteering finds a clear-cut positive and significant effect of income on volunteering without testing and/or controlling for potential endogeneity. These results are interpreted in support of the consumption hypothesis (see Section 3). Given our findings this conclusion seems premature.

The impact of age on voluntary labour supply shows ambiguous results too. Given our 
findings that the amount of volunteering decreases with age up to 44 years, we find further evidence in support of the investment motive. The older an individual, the lower is her investment in human capital and the smaller are the profits from networks provided by volunteering work (Supposition 4). On the other hand we observe increasing volunteering activities for people older than 44 years, respectively. This contradicts the investment model and provides evidence for the consumption model. The result is in line with Brendgens and Braun (2000) who find that retired people are more altruistically motivated and focus more on consumption. One possible explanation is that the motives for volunteering change over time and people - as they get older - conceive volunteering as investment in their mental and physical health (Thoits and Hewiit, 2001; Meier and Stutzer, 2004) or as pure amusement.

Women, individuals residing in urban areas and people living in a partnership are less likely to offer voluntary labour. ${ }^{9}$ The fact that women volunteer significantly less may be explained by child care responsibilities and a higher engagement in informal help. ${ }^{10}$ The influence of residing in an urban area can be explained by the different social structure in rural areas as compared to large cities with a stronger corporate attitude to be expected in rural areas. This is supported by Smith (1994), Wuthnow (1998) and Wilson (2000). Furthermore, the lack of alternative leisure activities in rural areas makes volunteering more attractive and decreases opportunity cost of volunteering. The negative impact of a cohabiting partner probably reflects tighter time constraints. Self employment is not significant. Whereas a volunteering partner increases the probability of own engagement by 0.51 individuals who joined a club during childhood and adolescence volunteer increase their probability to volunteer by 0.14 . We do not find a statistically significant impact of education which is in contrast to a number of studies finding a positive or even a negative influence of education on formal labor supply (Busching, 1987; Clary, Snyder and Stukas, 1996; McPherson and Rotolo, 1996; Brady, Schlozman and Verba, 1999; Gibson, 1999; Wilson, 2000). However, Omoto and Snyder (1993) and Wilson (2000) confirm an insignificant influence of education on informal volunteering.

An alternative method to regression analysis is provided by the matching method with its focus on estimating the causal effect of volunteering on the wage. One advantage of matching is the fact that this method does not require instrumental variables for volunteering. We set up a counterfactual framework introduced by Rubin (1974): For individual $i$ with $i=1 \ldots N$ let wage $_{i}(1)$ denote the wage rate when she is volunteering $\left(v_{i}=1\right)$ and wage $_{i}(0)$ if she is not volunteering $\left(v_{i}=0\right)$. If both wage $_{i}(1)$ and wage $_{i}(0)$ were observable the wage premium could be calculated as wage $_{i}(1)-$ wage $_{i}(0)$, and we observe

\footnotetext{
${ }^{9}$ The changes in the the predicted probabilities as these dummy variables change from 0 to 1 are -0.19 , -0.27 and -0.12 (marginal effects).

${ }^{10}$ For a comprehensive discussion of findings on gender differences in volunteer behaviour, see Wilson (2000).
} 
the so-called treatment effect of volunteering on the wage rate. Obviously, this situation can never be observed in non-experimental studies, and we face the problem of missing data. To overcome this problem matching methods compare two individuals in the data who only differ in their volunteer activity and coincide in their remaining socio-economic characteristics $\mathbf{X}_{\mathbf{1}}$. Different treatment effects can be estimated. The Average Treatment Effect $A T E$ calculates the expected effect of volunteering on the wage rate including every individual in the population irrespective whether she volunteers or not:

$$
A T E \equiv \mathbb{E}[\operatorname{wage}(1)-\operatorname{wage}(0)]=\frac{1}{N} \sum_{i=1}^{N}\left(\operatorname{wage}_{i}(1)-\operatorname{wage}_{i}(0)\right)
$$

A second quantity of interest represents the Average Treatment Effect on the Treated ATT, which averages the causal effect of the treatment across the subpopulation of volunteers. This is the average wage premium for those who actually volunteer:

$$
\begin{array}{r}
A T T \equiv \mathbb{E}[\operatorname{wage}(1)-\operatorname{wage}(0) \mid v=1] \\
=\frac{1}{N_{1}} \sum_{i \mid v_{i}=1}^{N}\left(\text { wage }_{i}(1)-\text { wage }_{i}(0)\right)
\end{array}
$$

For obvious reasons, the procedure suffers from multi-dimensionality which can jeopardise the matching strategy if many explaining variables have to be considered. Rosenbaum and Rubin (1983) propose Propensity Score Matching as an equivalent estimation strategy which reduces the dimensionality problem. The so-called propensity score is the probability of volunteering given the vector of socio-economic variables:

$$
p\left(\mathbf{X}_{\mathbf{1}}\right) \equiv \mathbf{P r}\left(v=1 \mid \mathbf{X}_{\mathbf{1}}\right)
$$

Any standard probability model can be used to estimate the propensity score which acts as an indicator for the similarity of individuals to be matched. In terms of the propensity score the ATT can be written as ${ }^{11}$ :

$$
\begin{gathered}
A T T \equiv \mathbb{E}\left[\mathbb{E}\left[\operatorname{wage}(1)-\operatorname{wage}(0) \mid p\left(\mathbf{X}_{\mathbf{1}}\right), v=1\right]\right] \\
=\mathbb{E}\left[\mathbb{E}\left[\operatorname{wage}(1) \mid p\left(\mathbf{X}_{\mathbf{1}}\right), v=1\right]-\mathbb{E}\left[\operatorname{wage}(0) \mid p\left(\mathbf{X}_{\mathbf{1}}\right), v=0\right] \mid v=1\right]
\end{gathered}
$$

The validity of matching relies on the so-called confoundness condition which means that the treatment assignment is independent of the outcomes conditional on the propensity score. Obviously, the probability of observing individuals with identical propensity scores tends to be zero. Hence, various methods are suggested for the definition of similarity from

\footnotetext{
${ }^{11}$ For more details on Propensity Score Matching, see Wooldridge (2002, ch. 18).
} 
which we apply Radius Matching, Kernel Matching, and Nearest Neighbour Matching. ${ }^{12}$

The explaining variables in the PROBIT estimation of the propensity score are similar to the structural variables in Table 3 except the wage which is the outcome of interest in this counterfactual framework. ${ }^{13}$ With a range from 20.1 percent to 26.9 percent the statistically significant ATTs are higher than the wage premia obtained from the regression analysis (see Table 5). These results again indicate a positive causal effect of volunteering on the wage rate and confirm the validity of the investment model.

\section{Investment motives of volunteering}

Subsequently, we explore the underlying motives behind the investment hypothesis in more depth. In particular we are interested whether the number of voluntary hours supplied and/or the number of organisations determine the wage premium. Whereas the number of volunteering hours can be associated with the acquisition of useful skills, the intensification of social contacts, and the opportunity to signal willingness to perform (Supposition 5 ), the number of organisations is attributed to the potential amount of social contacts (Supposition 6). Looking at Table 3 volunteering hours and the number of organisations are highly significant in explaining the wage premium. Nevertheless, these estimations do not allow the isolation of the partial influence of \#organisations (volunteer hours) since the equation does not control for volunteer hours (\#organisations). In a perfect setting this would require the simultaneous estimation of the decision to volunteer, the number or organisations, the volunteering hours and the wage rate.

Since the resulting system of equations seems empirically unmanageable we have chosen the following procedure: after controlling for self selection into volunteering and the potential simultaneity of volunteering and the wage rate we assume volunteering hours and number of organisations to be exogenous. Hence, we suppose that once we have controlled for the decision to volunteer the variables \#organisations, volunteer hours, (\#organisations) $^{2}$, and (volunteer hours) ${ }^{2}$ do not correlate with the structural error of the wage equation. Therefore, we employ a 2 SPROBITLS estimation to explain simultaneously $\ln$ (wage) and volunteer where we include volunteer hours, (volunteer hours) ${ }^{2}$, \#organisations and (\#organisations) ${ }^{2}$ in the second stage regression of the wage equation as exogenous variables.

The positive coefficient for volunteer hours and the negative coefficient for (volunteer hours $)^{2}$ in Table 6 indicate a decreasing marginal rate of return of hours on the wage rate. The maximal wage premium is given at 40 hours voluntary work per month. Though not statistically significant we also observe a decreasing marginal return of the number

\footnotetext{
${ }^{12}$ For details, see Becker and Ichino (2002).

${ }^{13}$ The results from the propensity score estimation are available upon request.
} 
of organisations with the maximum wage premium at 3.1 organisations. These empirical findings support the idea that volunteering up to a certain amount of time might signal ability and willingness to perform. However, if the optimal amount of volunteering hours is exceeded employers could fear a lack of commitment in the paid job resulting in falling wage premia. The coefficients of the other variables in the wage equation show expected signs and are very similar to the estimated models presented in Table 3.

To gain further evidence on the underlying motives of the investment model we again apply Propensity Score Matching. Within the group of volunteers three different treatments are designed: (i) Whether a person volunteers more than the sample median of voluntary hours supplied. (ii) Whether a person volunteers more than the sample mean of voluntary hours supplied. (iii) Whether a person volunteers for more than one organisation. ${ }^{14}$ As indicated by the ATTs in Table 7 an increase of working hours beyond the sample median raises the wage by $24.4,22.0$ or 16.8 percent depending on the matching estimator with the Kernel and Radius results being statistically significant. With 21.2, 17.9 and 7.1 percent the corresponding values based on the 'mean treatment' are lower as compared to the 'median-treatment'. Given that the median of volunteer hours is smaller than the mean we obtain a confirmation of decreasing marginal returns of volunteer hours. Again the Kernel and Radius methods provide statistically significant ATTs. With a wage premium from 7.2 percent (Kernel and Nearest Neighbor) to 8.1 percent (Radius) the treatment based on the number of organisations provides lower results. However, these results are statistically insignificant.

Both the 2SProBitLS results from Table 6 and the matching estimations (Table 7) confirm a significant influence of voluntary hours on the wage rate. Apparently, the acquisition of useful skills and the intensification of social contacts (facilitated by a high number of voluntary hours) and their impact on human capital play an important role for the explanation of volunteering behaviour. Signalling an individual's willingness to perform is another explanation concurring with this empirical evidence (Supposition 5).

The other suppositions based on the investment model cannot be supported by our data: As far as the pure number of social contacts is concerned we have not found a statistical influence of the number of organisations as shown above (Supposition 6). Hence, it is not the amount of organisations and the associated quantitative number of potential contacts which is important for networking - rather the existence of intensified social contacts measured in volunteering hours seems decisive for the network motive to be valid. Based on Supposition 7 we tested whether more influential and bigger organisations would guarantee higher wage premia. Introducing various dummies for certain types of organisations in our regression analyses we have not found statistical evidence for the

\footnotetext{
${ }^{14}$ The results from the three PROBIT estimations which have been used for the calculation of propensity scores are available upon request.
} 
validity of Supposition 7. The same is true for Supposition 8 predicting a higher probability to volunteer for unemployed people or people willing to enter the labour force again - we do not find according evidence. ${ }^{15}$

In order to check the robustness of our results, we have carried out all estimations for the whole sample of all employed individuals. Thereby, we have increased our sample size to 1,383 observations, but have switched from using the individual income to household income. The results are very stable, and we observe the same pattern as for the sample of single earners only. ${ }^{16}$

\section{Summary and Conclusions}

This paper analyses motives for the decision to volunteer. The analysis is based on the interpretation of volunteering as a common consumption good (consumption model) or as a mean to increase an individual's human capital (investment model). Whereas existing literature provides evidence on the validity of these models, available empirical results are ambiguous. Most of the available results must be questioned at least partly due to methodological difficulties which are not considered adequately.

We present a solid empirical framework to address different hypotheses on volunteering decisions with appropriate econometric methods. The paper differs from previous work by

- empirically controlling for potential simultaneity due to the interdependence between income and the volunteering decision.

- accounting for self selection of volunteers since volunteers differ systematically to non volunteers in (un)observed characteristics determining income.

- investigating the underlying motives behind the investment model.

- measuring volunteering in three different dimensions.

The consistency of results from the instrumental variables approach and the propensity score matching allows the following summary: We find statistical evidence for the investment model with a highly robust and significant causal effect of volunteering on the wage

\footnotetext{
${ }^{15}$ Regression results for Suppositions 7 and 8 are not reported in the paper but available upon request.

${ }^{16}$ The following plausible changes for the regression analysis are: (i) Lower wage premia, since the change from the individual income to the household income decreases the effect of volunteering. (ii) The endogeneity of the income is more clear-cut, and the instrumental variables for income do not pass the overidentification tests. This result is plausible since the instruments are intended to work for individual income. (iii) We find a statistically significant effect of income on all dimensions of volunteering. The last result can either indicate the consumption motive if the household income is used as the relevant income variable or may simply reflect the remaining endogeneity since the instruments perform poorly.
} 
rate. On average the wage premium for volunteering amounts up to 18.5 percent in the regression analysis. Within the framework of the investment model it turns out that the number of volunteering hours plays an important role in explaining the wage premium. This supports the significance of skill acquisition to accumulate human capital, the importance of deepening of social contacts and signalling willingness to perform. However, no evidence is found for other motives associated with the investment model. The quantitative number of social contacts measured by the number of organisations does not generate a wage premium.

As far as the consumption motive is concerned we do not find clear statistical evidence for its validity. However, even in the absence of a significant impact of income on volunteering, we cannot rule out the validity of the consumption model. A certain type of preference structure might explain this outcome as well (e.g. quasi-linear preferences, substitution and income effects might cancel). In addition we find some evidence that people seem to change their motives for volunteering over time: When people grow older, they may offer voluntary labour in order to preserve their mental and physical health or to enjoy themselves.

Several conclusions can be drawn from this analysis. The strong evidence for the investment model with its significant influence of volunteering on the wage rate requires the inclusion of volunteering variables in the estimation of wage equations. From an individual's perspective the existence of the wage premium is an important determinant of the decision to volunteer. Hence, our results can further be exploited as a striking argument in the recruitment process of volunteers for several organisations. Moreover, the results may challenge previous empirical findings on volunteering. Many papers report a positive and significant influence of income on the volunteering decision without adequately taking endogeneity based on self selection and simultaneity into account. Therefore, it remains open whether this positive influence is in support of the consumption model or occurs as a result of econometric misspecification. We offer a promising procedure for the appropriate analysis of unpaid labour and take into account the underlying econometric structure of this type of labour supply - an approach which could successfully be implemented for panel data which allows the calculation of individual fixed-effects.

\section{References}

Altenstraßer, Christine, Franz Hackl and Gerald J. Pruckner (2002), Ehrenamtlichkeit und die Volkswirtschaftliche Bedeutung des Roten Kreuzes, Endbericht, Institut für Volkswirtschaftslehre, Universität Linz. 
Amemiya, Takeshi (1978), 'The Estimation of a Simultaneous Equation Generalized Probit Model', Econometrica 46(5), 1193-1205.

Andreoni, James (1990), 'Impure Altruism and Donations to Public Goods: A Theory of Warm-Glow Giving', Economic Journal 100(401), 464-477.

Andreoni, James, William G. Gale and John K. Scholz (1996), Charitable Contributions of Time and Money, Working paper, Department of Economics, University of WisconsinMadison.

Argyle, Michael (1999), Causes and Correlates of Happiness, in D.Kahneman, E.Diener and N.Schwarz, eds, 'Well-Being: The Foundations of Hedonic Psychology'.

Baum, Christopher F., Mark E. Schaffer and Steven Stillman (2003), 'Instrumental Variables and GMM: Estimation and Testing', Stata Journal 3(1), 1-31.

Becker, Sascha O. and Andrea Ichino (2002), 'Estimation of Average Treatment Effects Based on Propensity Scores', Stata Journal 2(4), 358-377.

Brady, Henry E., Kay L. Schlozman and Sidney Verba (1999), 'Prospecting for Participants: Rational Expectations and the Recruitment of Political Activists', American Political Science Review 93, 153-169.

Brendgens, Ulrich and Joachim Braun (2000), Freiwilliges Engagement der Senioren und Seniorinnen, in B.von Rosenbladt, ed., 'Ergebnisse der Repräsentativerhebung $1999 \mathrm{zu}$ Ehrenamt, Freiwilligenarbeit und bürgerschaftlichem Engagement', Kohlhammer, Köln, pp. $156-166$.

Bryant, Keith W., Haekyung Jeon-Slaughter, Hyojin Kang and Aaron Tax (2003), 'Participation in Philantropic Activities: Donating Money and Time', Journal of Consumer Policy 26(1), 43-73.

Bureau of Labor Statistics (2002), Volunteering in the United States, 2002, Economic news releases, Washington, D.C.

Bureau of Labor Statistics (2003), Volunteering in the United States, 2003, Economic news releases, Washington, D.C.

Bureau of Labor Statistics (2004), Volunteering in the United States, 2004, Economic news releases, Washington, D.C.

Bureau of Labor Statistics (2005), Volunteering in the United States, 2005, Economic news releases, Washington, D.C.

Busching, William (1987), 'An Examination of Volunteering Among Members of a Fraternal Benefit Society Employing the ISSTAL and General Activity Models', Journal of Voluntary Action Research 6(4), 69-85.

Cahuc, Pierre and André Zylberberg (2004), Labor Economics, MIT Press, Cambridge, MA.

Cappellari, Lorenzo and Gilberto Turati (2004), 'Volunteer Labour Supply: The Role of Workers' Motivations', Annals of Public and Cooperative Economics 75(4), 619-643. 
Carlin, Paul S. (2001), 'Evidence on the Volunteer Labor Supply of Married Women', Southern Economic Journal 67(4), 801-824.

Clary, Gil E., Mark Snyder and Arthur A. Stukas (1996), 'Volunteers Motivations: Findings From a National Survey', Nonprofit and Voluntary Sector Quarterly 25(4), 485-505.

Cugno, Franco and Mario Ferrero (2004), 'Competition Among Volunteers', European Journal of Political Economy 20(3), 637-654.

Day, Kathleen M. and Rose A. Devlin (1996), 'Volunteerism and Crowding Out: Canadian Econometric Evidence', Canadian Journal of Economics 29(1), 37-53.

Day, Kathleen M. and Rose A. Devlin (1997), 'Can Volunteer Work Help Explain the Male-Female Earnings Gap?', Applied Economics 29(6), 707-721.

Day, Kathleen M. and Rose A. Devlin (1998), 'The Payoff to Work Without Pay: Volunteer Work as an Investment in Human Capital', Canadian Journal of Economics 31(5), 1179-1191.

Deci, Edward L. (1975), Intrinsic Motivation, Plenum Press, New York.

Deci, Edward L. and Richard M. Ryan (2000), "The "What" and "Why" of Goal Pursuits: Human Needs and The Self-Determination of Behavior', Psychological Inquiry 11(4), 227-268.

Devlin, Rose A. (2000), Labour-Market Responses to Volunteering - Evidence from the 1997 SGVP, Working Paper R-00-5-1E, Human Resources Development Canada, Strategic Policy, Applied Research Branch, Ottawa.

Dye, Richard F. (1980), 'Contributions of Volunteer Time: Some Evidence on Income Tax Effects', National Tax Journal 33(1), 89-93.

Freeman, Richard B. (1997), 'Working for Nothing: the Supply of Volunteer Labor', Journal of Labor Economics 15(1), S140-S166.

Frey, Bruno S. (1997), 'A Constitution for Knaves Crowds Out Civic Virtues', Economic Journal 107(443), 1043-1053.

Frey, Bruno S. and Lorenz Goette (1999), Does Pay Motivate Volunteers?, Working Paper Series 7, Institute for Empirical Reasearch in Economics, University of Zurich.

Gibson, John (1999), 'Correlation Versus Causation and the Apparent External Benefits of Education', New Zealand Economic Papers 33(1), 51-69.

Govekar, Paul L. and Michele A. Govekar (2002), 'Using Economic Theory and Research to Better Understand Volunteer Behaviour', Nonprofit Management and Leadership 13(1), 33-48.

Hackl, Franz and Gerald J. Pruckner (2003), 'Wertschätzung für Erste Hilfe - eine ökonomische Analyse des Roten Kreuzes', Journal of Public Health/Zeitschrift für Gesundheitswissenschaften 1(12), 50-60. 
Hwang, Monica, Edward Grabb and James Curtis (2005), 'Why Get Involved? Reasons for Voluntary-Association Activity among Americans and Canadians', Nonprofit and Voluntary Sector Quarterly 34(3), 387-403.

Katz, Eliakim and Jacob Rosenberg (2005), 'An Economic Interpretation of Institutional Volunteering', European Journal of Political Economy 21(2), 429-443.

Keshk, Omar M. G. (2003), 'CDSIMEQ: A Program to Implement Two-Stage Probit Least Squares', The Stata Journal 3(2), 1-11.

Liu, Pak-Wai and Junsen Zhang (1999), 'Assortative Mating versus the Cross-Productivity Effect', Applied Economics Letters 6(8), 523-525.

Maddala, G S (1983), Limited-Dependent and Qualitative Variables in Econometrics, Cambdridge University Press, Cambdridge.

McPherson, J. and Thomas Rotolo (1996), 'Diversity and Change in Voluntary Group', American Sociological Review 61, 179-202.

Meier, Stephan (2006), The Economics of Non-selfish Behaviour: Decisions to Contribute Money to Public Goods, Edward Elgar, Cheltenham.

Meier, Stephan and Alois Stutzer (2004), Is Volunteering Rewarding in Itself?, Working Paper Series 180, Institute for Empirical Research in Economics, University of Zurich.

Menchik, Paul L. and Burton A. Weisbrod (1987), 'Volunteer Labour Supply', Journal of Public Economics 32(2), 159-183.

Mueller, Marnie W. (1975), 'Economic Determinants of Volunteer Work by Women', Signs: Journal of Women in Culture and Society 1(2), 325-338.

Newey, Whitney K. (1987), 'Efficient Estimation of Limited Dependent Variable Models with Endogenous Explanatory Variables', Journal of Econometrics 36, 231-250.

Omoto, Allen and Mark Snyder (1993), 'Volunteer and their Motivations: Theoretical Issues and Practical Concerns', Nonprofit Management Leadership 4, 157-176.

Prouteau, Lionel and François-Charles Wolff (2005), 'Does Voluntary Work Pay Off in the Labor Market?', Journal of Socio-Economics (forthcoming).

Rivers, Douglas and Quang H. Vuong (1988), 'Limited Information Estimators and Exogeneity Tests for Simultaneous Probit Models', Journal of Econometrics 39(3), 347-366.

Rosenbaum, Paul R. and Donald B. Rubin (1983), 'The Central Role of the Propensity Score in Observational Studies for Causal Effects', Biometrika 70(1), 41-55.

Rubin, Donald B. (1974), 'Estimating Causal Effects of Treatments in Randomized and Nonrandomized Studies', Journal of Educational Pyschology 66(5), 688-701.

Saloner, Garth (1985), 'Old Boy Networks as Screening Mechanisms', Journal of Labor Economics 3(3), 255-267.

Sargan, John D. (1958), 'The Estimation of Economic Relationships Using Instrumental Variables', Econometrica 26(3), 393-415. 
Schady, Norbert R. (2001), Who Participates? The Supply of Volunteer Labor and the Distribution of Government Programs in Rural Peru, Working Paper 2671, World Bank, Washington, DC.

Schram and Dunsig (1981), 'Influences on Married Women's Volunteer Work Participation', Journal of Consumer Research 7(4), 372-379.

Segal, Lewis M. and Burton A. Weisbrod (2002), 'Volunteer Labor Sorting Across Industries', Journal of Policy Analysis and Management 21(3), 427-447.

Smith, David H. (1994), 'Determinants of Voluntary Association Participation and Volunteering: A Literature Review', Nonprofit and Voluntary Sector Quarterly 23(3), 243263.

Smith, Richard J. and Richard W. Blundell (1986), 'An Exogeneity Test for a Simultaneous Equation Tobit Model with an Application to Labor Supply', Econometrica 54(4), 679686.

Stark, Oded (1995), Altruism and Beyond - An Economic Analysis of Transfers and Exchanges within Families and Groups, Cambridge University Press, Cambridge.

Thoits, Peggy A. and Lyndi N. Hewiit (2001), 'Volunteer Work and Well-Being', Journal of Health and Social Behavior 42(2), 115-131.

Unger, Lynette S. (1991), 'Altruism as a Motivation to Volunteer', Journal of Economic Psychology 12(1), 71-100.

Vaillancourt, François (1994), 'To Volunteer or Not: Canada, 1987', Canadian Journal of Economics 27(4), 813-825.

Wilson, John (2000), 'Volunteering', Annual Review of Sociology 26, 15-40.

Wooldridge, Jeffrey M. (2002), Econometric Analysis on Cross Section and Panel Data, MIT Press, Cambridge, MA.

Wuthnow, Robert (1998), Loose Connections: Joining Together in America's Fragmented Communities, Harvard University Press, Cambridge, MA.

Ziemek, Susanne (2003), The Economics of Volunteer Labor Supply An Application to Countries of a Different Development Level, Europäischer Verlag der Wissenschaften, Frankfurt/Main. 
Table 1: Participation in Voluntary Labour in Europe ${ }^{a}$

\begin{tabular}{lcc}
\hline \hline & Mean & Obs. \\
\cline { 2 - 3 } Sweden & 0.59 & 716 \\
Slovakia & 0.55 & 725 \\
The Netherlands & 0.49 & 551 \\
Great Britain & 0.46 & 395 \\
Greece & 0.42 & 672 \\
Denmark & 0.41 & 618 \\
Finland & 0.39 & 526 \\
Belgium & 0.39 & 763 \\
Ireland & 0.39 & 421 \\
Czech Republic & 0.37 & 921 \\
Austria & 0.35 & 610 \\
Slovenia & 0.32 & 396 \\
Malta & 0.32 & 350 \\
Iceland & 0.31 & 603 \\
Luxembourg & 0.31 & 402 \\
Italy & 0.31 & 765 \\
France & 0.28 & 692 \\
Latvia & 0.28 & 458 \\
Romania & 0.27 & 489 \\
Croatia & 0.27 & 578 \\
Bulgaria & 0.26 & 415 \\
Northern Ireland & 0.25 & 322 \\
Belarus & 0.24 & 650 \\
Spain & 0.23 & 353 \\
Estonia & 0.22 & 541 \\
Germany & 0.21 & 483 \\
Lithuania & 0.19 & \\
Poland & 0.18 & \\
Hungary & 0.18 & \\
Ukraine & 0.16 & \\
Russia & 0.12 & \\
Turkey & 0.10 & \\
\hline Overall & 0.31 & \\
\hline \hline
\end{tabular}

${ }^{a}$ Own calculations based on data from the European Values Survey (EVS) for the year 1999 (employed individuals only). The EVS contains information on basic attitudes, beliefs and human values covering religion, morality, politics, work and leisure. In all countries representative national samples were interviewed. Obs. is the number of available observations. 
Table 2: Single Equation Results for Volunteering and Income ${ }^{a}$

\begin{tabular}{|c|c|c|}
\hline Method of Estimation & $\begin{array}{c}\text { OLS } \\
\ln (\text { wage })\end{array}$ & $\begin{array}{l}\text { PROBIT } \\
\text { volunteer }\end{array}$ \\
\hline volunteer & $\begin{array}{c}0.236 \\
(0.045)^{* * *}\end{array}$ & \\
\hline $\ln ($ wage $)$ & & $\begin{array}{c}0.773 \\
(0.178)^{* * *}\end{array}$ \\
\hline school & $\begin{array}{c}0.068 \\
(0.012)^{* * *}\end{array}$ & $\begin{array}{c}0.014 \\
(0.041)\end{array}$ \\
\hline exper & $\begin{array}{c}0.011 \\
(0.008)\end{array}$ & $\begin{array}{c}-0.084 \\
(0.028)^{* * *}\end{array}$ \\
\hline$(\text { exper })^{2}$ & $\begin{array}{l}-0.0002 \\
(0.0002)\end{array}$ & $\begin{array}{c}0.002 \\
(0.001)^{* * *}\end{array}$ \\
\hline self employed & $\begin{array}{c}0.098 \\
(0.103)\end{array}$ & $\begin{array}{c}0.591 \\
(0.374)\end{array}$ \\
\hline female & $\begin{array}{c}-0.095 \\
(0.051)^{*}\end{array}$ & $\begin{array}{c}-0.545 \\
(0.164)^{* * *}\end{array}$ \\
\hline partner & $\begin{array}{c}0.097 \\
(0.047)^{* *}\end{array}$ & $\begin{array}{c}-0.365 \\
(0.154)^{* *}\end{array}$ \\
\hline urban & $\begin{array}{c}0.041 \\
(0.047)\end{array}$ & $\begin{array}{c}-0.808 \\
(0.164)^{* * *}\end{array}$ \\
\hline workhours & $\begin{array}{c}-0.017 \\
(0.003)^{* * *}\end{array}$ & $\begin{array}{c}0.015 \\
(0.010)\end{array}$ \\
\hline shift worker & $\begin{array}{c}0.128 \\
(0.050)^{* *}\end{array}$ & \\
\hline household members & $\begin{array}{c}0.029 \\
(0.018)\end{array}$ & \\
\hline blue collar & $\begin{array}{c}-0.100 \\
(0.051)^{*}\end{array}$ & \\
\hline partner volunteers & & $\begin{array}{c}1.565 \\
(0.341)^{* * *}\end{array}$ \\
\hline youth club & & $\begin{array}{c}0.410 \\
(0.160)^{* *}\end{array}$ \\
\hline constant & $\begin{array}{c}1.839 \\
(0.226)^{* * *}\end{array}$ & $\begin{array}{c}-1.733 \\
(0.766)^{* *}\end{array}$ \\
\hline$R^{2}$ & 0.290 & \\
\hline McFadden's Pseudo $R^{2}$ & & 0.225 \\
\hline
\end{tabular}

${ }^{a}$ In each estimation the number of observations is 421 . Standard errors are in parentheses. ${ }^{*},{ }^{*}$ and $* * *$ indicate statistical significance at the 10 -percent level, 5-percent level and 1-percent level. 
Table 3: Estimations of the Consumption and Investment Motive ${ }^{a}$

\begin{tabular}{|c|c|c|c|c|c|c|}
\hline \multirow{2}{*}{$\begin{array}{l}\text { Methods Of Esti- } \\
\text { MATION }\end{array}$} & \multicolumn{2}{|c|}{ 2SPRoBitLS ${ }^{b}$} & \multicolumn{2}{|c|}{ 2SToвITLS } & \multicolumn{2}{|c|}{ 2SToвITLS } \\
\hline & $\ln ($ wage $)$ & volunteer & $\ln (\text { wage })^{c}$ & volunteer hours & $\ln (\text { wage })^{c}$ & \#organisations \\
\hline volunteer & $\begin{array}{c}0.185 \\
(0.044)^{* * *}\end{array}$ & & & & & \\
\hline volunteer hours & & & $\begin{array}{c}0.006 \\
(0.002)^{* * *}\end{array}$ & & & \\
\hline \#organisations & & & & & $\begin{array}{c}0.170 \\
(0.051)^{* * *}\end{array}$ & \\
\hline $\ln$ (wage) & & $\begin{array}{c}0.730 \\
(0.956)\end{array}$ & & $\begin{array}{c}56.067 \\
(37.680)\end{array}$ & & $\begin{array}{c}0.774 \\
(1.510)\end{array}$ \\
\hline school & $\begin{array}{c}0.057 \\
(0.013)^{* * *}\end{array}$ & $\begin{array}{l}0.020 \\
(0.081)\end{array}$ & $\begin{array}{c}0.058 \\
(0.017)^{* * *}\end{array}$ & $\begin{array}{l}-1.499 \\
(3.137)\end{array}$ & $\begin{array}{c}0.059 \\
(0.016)^{* * *}\end{array}$ & $\begin{array}{c}0.035 \\
(0.124)\end{array}$ \\
\hline exper & $\begin{array}{c}0.021 \\
(0.009)^{* *}\end{array}$ & $\begin{array}{c}-0.081 \\
(0.030)^{* * *}\end{array}$ & $\begin{array}{c}0.028 \\
(0.013)^{* *}\end{array}$ & $\begin{array}{c}-3.928 \\
(1.063)^{* * *}\end{array}$ & $\begin{array}{c}0.016 \\
(0.010)\end{array}$ & $\begin{array}{l}-0.062 \\
(0.039)\end{array}$ \\
\hline$(\text { exper })^{2}$ & $\begin{array}{c}-0.0004 \\
(0.0002)^{* *}\end{array}$ & $\begin{array}{c}0.002 \\
(0.0006)^{* *}\end{array}$ & $\begin{array}{c}-0.001 \\
(0.0003)^{* * *}\end{array}$ & $\begin{array}{c}0.073 \\
(0.023)^{* * *}\end{array}$ & $\begin{array}{c}-0.0003 \\
(0.0002)\end{array}$ & $\begin{array}{c}0.001 \\
(0.0008)\end{array}$ \\
\hline self employed & $\begin{array}{c}0.149 \\
(0.106)\end{array}$ & $\begin{array}{l}-0.543 \\
(0.377)\end{array}$ & $\begin{array}{c}0.200 \\
(0.408)\end{array}$ & $\begin{array}{l}-25.132 \\
(15.302)\end{array}$ & $\begin{array}{c}0.178 \\
(0.252)\end{array}$ & $\begin{array}{l}-0.702 \\
(0.500)\end{array}$ \\
\hline female & $\begin{array}{l}-0.013 \\
(0.060)\end{array}$ & $\begin{array}{c}-0.507 \\
(0.196)^{* * *}\end{array}$ & $\begin{array}{c}0.055 \\
(0.081)\end{array}$ & $\begin{array}{c}-21.310 \\
(7.600)^{* * *}\end{array}$ & $\begin{array}{c}0.042 \\
(0.082)\end{array}$ & $\begin{array}{c}-0.782 \\
(0.281)^{* * *}\end{array}$ \\
\hline partner & $\begin{array}{c}0.087 \\
(0.048)^{*}\end{array}$ & $\begin{array}{l}-0.326 \\
(0.175)^{*}\end{array}$ & $\begin{array}{c}0.116 \\
(0.060)^{* *}\end{array}$ & $\begin{array}{c}-16.789 \\
(6.719)^{* *}\end{array}$ & $\begin{array}{c}0.092 \\
(0.060)\end{array}$ & $\begin{array}{l}-0.398 \\
(0.246)\end{array}$ \\
\hline urban & $\begin{array}{c}0.140 \\
(0.050)^{* *}\end{array}$ & $\begin{array}{c}-0.764 \\
(0.161)^{* * *}\end{array}$ & $\begin{array}{c}0.133 \\
(0.071)^{*}\end{array}$ & $\begin{array}{c}-22.145 \\
(6.146)^{* * *}\end{array}$ & $\begin{array}{c}0.190 \\
(0.083)^{* *}\end{array}$ & $\begin{array}{c}-1.123 \\
(0.222)^{* * *}\end{array}$ \\
\hline workhours & $\begin{array}{c}-0.016 \\
(0.003)^{* * *}\end{array}$ & $\begin{array}{c}0.014 \\
(0.018)\end{array}$ & $\begin{array}{c}-0.018 \\
(0.004)^{* * *}\end{array}$ & $\begin{array}{c}1.201 \\
(0.710)^{*}\end{array}$ & $\begin{array}{c}-0.017 \\
(0.005)^{* * *}\end{array}$ & $\begin{array}{c}0.020 \\
(0.027)\end{array}$ \\
\hline shift worker & $\begin{array}{c}0.108 \\
(0.051)^{* *}\end{array}$ & & $\begin{array}{c}0.095 \\
(0.056)^{*}\end{array}$ & & $\begin{array}{c}0.124 \\
(0.054)^{* *}\end{array}$ & \\
\hline household members & $\begin{array}{c}0.039 \\
(0.018)^{* *}\end{array}$ & & $\begin{array}{c}0.031 \\
(0.022)\end{array}$ & & $\begin{array}{c}0.041 \\
(0.024)^{*}\end{array}$ & \\
\hline blue collar & $\begin{array}{l}-0.072 \\
(0.053)\end{array}$ & & $\begin{array}{l}-0.031 \\
(0.064)\end{array}$ & & $\begin{array}{l}-0.031 \\
(0.066)\end{array}$ & \\
\hline partner volunteers & & $\begin{array}{c}1.412 \\
(0.412)^{* * *}\end{array}$ & & $\begin{array}{c}30.263 \\
(13.613)^{* *}\end{array}$ & & $\begin{array}{c}1.398 \\
(0.518)^{* * *}\end{array}$ \\
\hline youth club & & $\begin{array}{c}0.391 \\
(0.192)^{* *}\end{array}$ & & $\begin{array}{l}12.092 \\
(7.548)\end{array}$ & & $\begin{array}{c}0.608 \\
(0.278)^{* *}\end{array}$ \\
\hline constant & $\begin{array}{c}1.926 \\
(0.227)^{* * *}\end{array}$ & $\begin{array}{l}-1.698 \\
(1.852)\end{array}$ & $\begin{array}{c}1.883 \\
(0.290)^{* * *}\end{array}$ & $\begin{array}{l}-119.425 \\
(72.093)^{*}\end{array}$ & $\begin{array}{c}1.915 \\
(0.283)^{* * *}\end{array}$ & $\begin{array}{l}-2.360 \\
(2.837)\end{array}$ \\
\hline
\end{tabular}

TEST FOR ENDOGENEITY OF $\left(H_{0}\right.$ : The variable is exogenous.)

volunteer $0.092^{d}$

volunteer hours $\quad 0.004^{d}$

\#organiations $\quad 0.004^{d}$

$\begin{array}{llll}\ln \text { (wage) } & 0.994^{e} & 0.460^{f} & 0.948^{f}\end{array}$

OVERIDENTIFICATION TEST OF ALL INSTRUMENTS FOR $\left(H_{0} \text { : The instruments are valid. }\right)^{g}$

volunteer $\quad 0.819$

volunteerhours $\quad 0.560$

\#organisations

ln(wage) $\quad 0.190$

0.581

0.788

${ }^{a}$ In each estimation the number of observations is 421 (employed single earners only). Standard errors are in parentheses. ${ }^{*},{ }^{* *}$ and ${ }^{* * *}$ indicate statistical significance at the 10 -percent level, 5 -percent level and 1-percent level. ${ }^{b}$ The estimation is carried out by using Keshk (2003). ${ }^{c}$ Standard errors are bootstrapped based on 1000 replications. ${ }^{d} \mathrm{P}$-value of the Wu-Hausman statistic (Baum, Schaffer and Stillman, 2003). ${ }^{e}$ P-value of a test according to Rivers and Vuong (1988); see also Wooldridge (2002, Chap. 15, Procedure 15.1). ${ }^{f}$ P-value of a test according to Smith and Blundell (1986); see also Wooldridge (2002, Chap. 16, Procedure 16.1). ${ }^{g}$ P-value of Sargan statistic (Sargan, 1958). 
Table 4: Descriptive Statistics

\begin{tabular}{|c|c|c|c|}
\hline VARIABLE & DESCRIPTION & MEAN & S.D. \\
\hline blue collar & $\begin{array}{l}\text { One if the individual is a blue collar worker and zero if she is } \\
\text { a white collar worker. }\end{array}$ & 0.31 & 0.46 \\
\hline exper & Age minus the years of schooling minus six. & 21.41 & 10.42 \\
\hline household members & Number of household members & 2.03 & 1.40 \\
\hline $\ln ($ wage $)$ & $\begin{array}{l}\text { Ln of the individual hourly wage rate }(=\text { monthly income di- } \\
\text { vided by monthly working hours })\end{array}$ & 2.27 & 0.48 \\
\hline partner & One if the individual has a partner & 0.51 & 0.50 \\
\hline self-employed & One if the individual is self-employed & 0.04 & 0.20 \\
\hline shift worker & One if the individual is a shift worker & 0.21 & 0.41 \\
\hline urban & One if the individual resides in an urban area & 0.31 & 0.46 \\
\hline workhours & Hours of paid work per week & 39.16 & 7.87 \\
\hline youth club & $\begin{array}{l}\text { One if the individual was a club member during her adoles- } \\
\text { cence }\end{array}$ & 0.71 & 0.46 \\
\hline volunteer & One if the individual volunteers & 0.38 & 0.49 \\
\hline
\end{tabular}

Table 5: ATT of Volunteering on the Hourly Wage Rate ${ }^{a}$

\begin{tabular}{lllcc}
\hline \hline Method of Matching & ATT & t-value & $\begin{array}{c}\text { number of } \\
\text { treated }\end{array}$ & $\begin{array}{c}\text { number of } \\
\text { tontrols }\end{array}$ \\
\cline { 2 - 5 } Kernel & $26.9 \%$ & 5.610 & 162 & 259 \\
RAdius & $25.2 \%$ & 4.978 & 162 & 247 \\
NeAREst Neighbour & $20.1 \%$ & 2.632 & 162 & 89 \\
\hline \hline
\end{tabular}

${ }^{a}$ The number of observations is 421 (employed single earners only). The sample includes 162 individuals with and 259 without treatment. The outcome variable ist the logarithm of the hourly wage rate. We restrict the matching to the area of common support. The estimation follows Becker and Ichino (2002). ${ }^{b}$ The underlying standard errors are bootstrapped. 
Table 6: Motives for the Investment Motive ${ }^{a}$

\begin{tabular}{|c|c|c|}
\hline & \multicolumn{2}{|c|}{ 2SProbitLS } \\
\hline & $\ln ($ wage $)$ & volunteer \\
\hline volunteer & $\begin{array}{c}0.103 \\
(0.053)^{*}\end{array}$ & \\
\hline volunteer hours & $\begin{array}{c}0.008 \\
(0.004)^{* *}\end{array}$ & \\
\hline${\text { (volunteer hours })^{2}}^{2}$ & $\begin{array}{c}-0.0001 \\
(0.00004)\end{array}$ & \\
\hline \#organisations & $\begin{array}{c}0.055 \\
(0.096)\end{array}$ & \\
\hline (\#organisations) $^{2}$ & $\begin{array}{l}-0.009 \\
(0.034)\end{array}$ & \\
\hline $\ln ($ wage $)$ & & $\begin{array}{c}0.730 \\
(1.289)\end{array}$ \\
\hline school & $\begin{array}{c}0.060 \\
(0.015)^{* * *}\end{array}$ & $\begin{array}{c}0.020 \\
(0.105)\end{array}$ \\
\hline exper & $\begin{array}{c}0.022 \\
(0.010)^{* *}\end{array}$ & $\begin{array}{c}-0.081 \\
(0.031)^{* * *}\end{array}$ \\
\hline$(\text { exper })^{2}$ & $\begin{array}{c}-0.0004 \\
(0.0002)^{*}\end{array}$ & $\begin{array}{c}0.002 \\
(0.001)^{* *}\end{array}$ \\
\hline self employed & $\begin{array}{c}0.140 \\
(0.133)\end{array}$ & $\begin{array}{l}-0.543 \\
(0.441)\end{array}$ \\
\hline female & $\begin{array}{c}-0.010 \\
(0.061)\end{array}$ & $\begin{array}{c}-0.507 \\
(0.217)^{* *}\end{array}$ \\
\hline partner & $\begin{array}{c}0.087 \\
(0.056)\end{array}$ & $\begin{array}{l}-0.324 \\
(0.212)\end{array}$ \\
\hline urban & $\begin{array}{c}0.120 \\
(0.067)^{*}\end{array}$ & $\begin{array}{c}-0.764 \\
(0.180)^{* * *}\end{array}$ \\
\hline work hours & $\begin{array}{c}-0.017 \\
(0.004)^{* * *}\end{array}$ & $\begin{array}{c}0.014 \\
(0.025)\end{array}$ \\
\hline shift worker & $\begin{array}{c}0.098 \\
(0.052)^{*}\end{array}$ & \\
\hline household members & $\begin{array}{c}0.035 \\
(0.022)\end{array}$ & \\
\hline blue collar & $\begin{array}{c}-0.061 \\
(0.052)\end{array}$ & \\
\hline partner volunteers & & $\begin{array}{c}1.416 \\
(0.486)^{* * *}\end{array}$ \\
\hline youth club & & $\begin{array}{c}0.391 \\
(0.218)^{*}\end{array}$ \\
\hline constant & $\begin{array}{c}1.795 \\
(0.262)^{* * *}\end{array}$ & $\begin{array}{l}-1.699 \\
(2.491)\end{array}$ \\
\hline
\end{tabular}

${ }^{a}$ The number of observations is 421 (employed single earners only). Bootstrapped standard errors are in parentheses (1000 replications). *, ** and *** indicate statistical significance at the 10-percent level, 5-percent level and 1-percent level. Due to the assumption of conditional exogeneity the variables volunteer hours, (volunteer hours) ${ }^{2}$, \#organisations and (\#organisations) ${ }^{2}$ are included in the second stage regression only. 
Table 7: ATT of Volunteering more Hours than the Sample Median/Mean and of Volunteering for more than one Organization on the Hourly Wage Rate ${ }^{a}$

\begin{tabular}{|c|c|c|c|c|}
\hline MEthod OF MATCHING & $\mathrm{ATT}$ & t-value & $\begin{array}{c}\text { number of } \\
\text { treated }\end{array}$ & $\begin{array}{c}\text { number of } \\
\text { controls }\end{array}$ \\
\hline \multicolumn{5}{|l|}{ volunteer hours $>$ median $^{b}$} \\
\hline $\mathrm{KERNEL}^{e}$ & $24.4 \%$ & 2.915 & 71 & 91 \\
\hline RADIUS & $22.0 \%$ & 2.433 & 70 & 79 \\
\hline NeArest Neighbour & $16.8 \%$ & 0.912 & 71 & 29 \\
\hline \multicolumn{5}{|l|}{ volunteer hours $>$ mean $^{c}$} \\
\hline $\mathrm{KERNEL}^{e}$ & $21.2 \%$ & 2.867 & 63 & 99 \\
\hline RADIUS & $17.9 \%$ & 2.013 & 63 & 91 \\
\hline Nearest Neighbour & $7.1 \%$ & 0.530 & 63 & 33 \\
\hline \multicolumn{5}{|l|}{ \#organisations $>1^{d}$} \\
\hline $\mathrm{KERNEL}^{e}$ & $7.2 \%$ & 0.891 & 56 & 106 \\
\hline RADIUS & $8.1 \%$ & 0.845 & 51 & 87 \\
\hline Nearest Neighbour & $7.2 \%$ & 0.529 & 56 & 35 \\
\hline
\end{tabular}

${ }^{a}$ The number of observations is 421 (employed single earners only). The outcome variable ist the logarithmus of the hourly wage rate. We restrict the matching to the area of common support. The estimation follows Becker and Ichino (2002). $b$ The sample includes 71 individuals with and 91 without treatment. The median of volunteer hours is equal to $20 .^{c}$ The sample includes 99 individuals with and 63 without treatment. The mean of volunteer hours is equal to $29.55 .^{d}$ The sample includes 56 individuals with and 106 without treatment. The mean of \#organisations is equal to 1.48 . ${ }^{e}$ The underlying standard errors are bootstrapped. 